\title{
Precocity, yield and water-use efficiency of banana plants under planting densities and irrigation depths, in semiarid region ${ }^{1}$
}

\author{
Marcelo Rocha dos Santos², Sérgio Luiz Rodrigues Donato², \\ Diogo Barreto Magalhães ${ }^{2}$, Manoel Pereira Cotrim²
}

\section{ABSTRACT}

Banana is a crop of major importance for the Brazilian semiarid region. However, because of the low availability and irregularities of the rainfall in this area, it is necessary to combine techniques that allow a higher water-use efficiency. This study aimed to evaluate the influence of different combinations of irrigation depths and planting densities on the precocity, yield and water-use efficiency of BRS Platina banana plants, in the semiarid region of the Bahia state, Brazil. A randomized block design with four replicates was used, in a split-plot arrangement. Irrigation depths of $55 \%, 70 \%, 85 \%$ and $100 \%$ of the crop evapotranspiration (ETc) were assigned to the plot, and the planting densities of 1,600 plants $\mathrm{ha}^{-1}$, 2,000 plants ha-1 2,666 plants ha ${ }^{-1}$ and 3,333 plants hato the split-plot. The hands weight and number of fruits decreased in a linear way with the increase in the planting density (1,600 plants ha ${ }^{-1}$ to 3,333 plants ha $\left.{ }^{-1}\right)$ from $10.89 \mathrm{~kg}$ to $9.49 \mathrm{~kg}$ and from 97.16 to 89.86 , respectively; whereas the hands yield ( $15.5 \mathrm{t} \mathrm{ha}^{-1}$ to $\left.25.79 \mathrm{t} \mathrm{ha}^{-1}\right)$ and the harvest period (442 to 455 days) increased. The number of fruits increased linearly from 89.46 to 98.08 with the irrigation depth of $55 \%$ to $100 \%$ of the ETc. The yield and water-use efficiency increased linearly as the planting density increased (1,600 plants ha ${ }^{-1}$ to 3,333 plants ha-1) from 5.14 to 8.60 , while the water-use efficiency decreased with the irrigation depth from 7.97 to 5.50 , conidering $55 \%$ to $100 \%$ of the ETc. It is possible to obtain higher yields and a higher water-use efficiency by using a higher planting density and irrigation levels below $100 \%$ of the ETc.

KEYWORDS: Musa spp., irrigation management, plant population.

\section{INTRODUCTION}

Banana is the second (only behind orange) most produced fresh fruit in Brazil, with 6,764,324 t (Carvalho et al. 2017). The Northeast region is the largest producer, accounting for $35.79 \%$ of the

\section{RESUMO}

Precocidade, produtividade e eficiência de uso de água em bananeira sob densidades de plantio e lâminas de irrigação, em região semiárida

A bananeira é uma cultura de grande importância para o semiárido brasileiro. No entanto, devido à baixa disponibilidade e irregularidades de chuvas nesta região, torna-se necessário o uso de uma combinação de técnicas que permitam maior eficiência no uso de água. Objetivou-se avaliar a influência de combinações de lâminas de irrigação e densidades de plantio na precocidade, produtividade e eficiência de uso de água em bananeira BRS Platina, no semiárido do estado da Bahia. O delineamento experimental foi em blocos casualizados, com quatro repetições, distribuídas em parcelas subdivididas. Lâminas de irrigação de 55 \%, $70 \%, 85 \%$ e $100 \%$ da evapotranspiração da cultura (ETc) foram atribuídas à parcela, e densidades de plantio de 1.600 plantas $\mathrm{ha}^{-1}$, 2.000 plantas ha $^{-1}, 2.666$ plantas ha $^{-1}$ e 3.333 plantas ha $^{-1}$ à subparcela. $\mathrm{O}$ peso das pencas e o número de frutos diminuíram de forma linear com o aumento da densidade de plantio (1.600 plantas $\mathrm{ha}^{-1}$ para 3.333 plantas ha $\left.{ }^{-1}\right)$, passando de $10,89 \mathrm{~kg}$ para $9,49 \mathrm{~kg}$ e de 97,16 para 89,86 , respectivamente, enquanto a produtividade de pencas $\left(15,5 \mathrm{tha}^{-1}\right.$ para 25,79 tha $^{-1}$ ) e o período para colheita (442 para 455) aumentaram. O número de frutos aumentou linearmente de 89,46 para 98,08 com a lâmina de irrigação de $55 \%$ para $100 \%$ da ETc. O rendimento e a eficiência do uso de água aumentaram linearmente à medida em que a densidade de plantio (1.600 plantas ha- ${ }^{-1}$ para 3.333 plantas ha $^{-1}$ ) aumentou, passando de 5,14 para 8,60, e a eficiência do uso de água mostrou redução com a lâmina de irrigação, passando de 7,97 para 5,50 , considerando-se $55 \%$ a $100 \%$ da ETc. É possível obter maiores rendimentos e maior eficiência no uso de água utilizando-se maior densidade de plantio e nível de irrigação abaixo de $100 \%$ da ETc.

PALAVRAS-CHAVE: Musa spp., manejo de irrigação, população de plantas.

national production, while the Bahia state is the largest producer in this region, with $47.45 \%$ of the regional production (IBGE 2018).

The majority of the Brazilian Northeast region is semiarid, characterized by an average annual precipitation below $800 \mathrm{~mm}$ and aridity index of 0.5 , 
calculated by water balance using data from 1961 to 1990 , exhibiting a drought risk higher than $60 \%$ (Pereira Junior 2007). However, large productive areas with a great potential for increasing the agricultural production are prominent, and irrigation is needed to enable this agricultural production. The crop water demand is higher than its availability in this region, where, in many occasions, the availability of water resources has collapsed.

From a sustainability standpoint, increasing the irrigation and water-use efficiency is indispensable in this region. Thus, farmers should adopt more efficient irrigation systems, invest in modern water-saving technologies and in yield-increasing methods, in an attempt to reduce the water loss by evaporation.

Increased crop water-use efficiency is essential when farming in semiarid regions with scarce water resources. Water-use efficiency can be defined as the ratio of the commercial yield to the water effectively used by the crop as evapotranspiration (Jesen 2007). Simsek et al. (2005) and Zhang et al. (2004) computed the water-use efficiency by the ratio between the commercial yield and crop evapotranspiration, while Aujla et al. (2005) used a ratio between yield and the total amount of water received by the plants (irrigation + precipitation). Water-use efficiency may be increased by reducing the irrigation depth, what might save water and increase profits without decreasing yield (Melo et al. 2010, Teixeira et al. 2011, Oliveira et al. 2013).

To increase the water-use efficiency, cultivation practices can be applied to increase the crop yield, as well as to reduce the crop evapotranspiration (ETc). The increase in yield can be attained by simply choosing a cultivar that is either high yielding or adapted to the growing environment, better crop practices, adequate plant spacing, higher planting density, fertilization, and pest and disease control. The ETc can be decreased by reducing both the evaporation from wet surfaces (soil and plant) and transpiration.

Production strategies such as increasing the planting density under semiarid conditions and protecting the crop from the wind decrease the excess of solar radiation; reduce the emergence of weeds, what decreases the use of herbicides; help to cool down the plants; reduce the water evaporation from the soil; and improve the growth, development and yield of banana plants (Donato et al. 2015a). Moreover, the increase in planting density can increase the water-use efficiency, as yield might increase, but the evapotranspiration would remain the same. Nevertheless, the increase in planting density should maintain the fruit physical and chemical quality.

Several studies on increasing the planting density of bananas are found in the literature, particularly for Cavendish (Flori et al. 2004, Langdon et al. 2008, Mahmoud 2013, Nomura et al. 2013) and plantain (Rosales et al. 2008, Cavalcante et al. 2014, Prata et al. 2018, Ulloa Cortazar et al. 2017) cultivars, which greatly differ positively from the Prata-type banana cultivars. Studies have been conducted using Prata-Anã (Pereira et al. 2000); however, no information is available for BRS Platina.

Using the High Density Planting technique in India, Mahmoud (2013) reported yield improvements by recording a heavier bunch weight $(37.67 \mathrm{~kg}$ ), yield of $123 \mathrm{t} \mathrm{ha}^{-1}$, increase in water productivity, and a better benefit-cost ratio for the production cycle of Grand Nain mother-plants (genomic group AAA, Musa acuminata) irrigated by dripping and grown in a spacing of $1.75 \mathrm{~m} \times 1.75 \mathrm{~m}(3,265$ plants ha-1), with water application of $764.26 \mathrm{~mm}$ year $^{-1}$ and fertilization of 160:32:192 $\mathrm{g} \mathrm{plant}^{-1}$ year $^{-1}$ of NPK, applied through fertigation. The aforementioned condition was compared to spacing combinations $(1.5 \mathrm{~m} \times 1.5 \mathrm{~m}$ and $1.25 \mathrm{~m} \times 1.25 \mathrm{~m}$, respectively for 4,444 plants ha $\mathrm{h}^{-1}$ and 6,400 plants ha ${ }^{-1}$ ), water levels $\left(1,145.40 \mathrm{~mm}\right.$ year-1 and $1,546.4 \mathrm{~mm}^{-1}$ year $\left.{ }^{-1}\right)$ and fertigation (240:48:288 $\mathrm{g} \mathrm{plant}^{-1}$ year $^{-1}$ and 200:40:250 g plant $^{-1}$ year $^{-1}$ of N:P:K, respectively). The highest yield observed in the mother-plant cycle was $229.30 \mathrm{t} \mathrm{ha}^{-1}$ for the plants grown in a spacing of $1.25 \mathrm{~m} \mathrm{x} 1.25 \mathrm{~m}$, irrigated with $765.26 \mathrm{~mm}$ year $^{-1}$ and fertilized with 240:48:288 g plant $^{-1}$ year $^{-1}$ of N:P:K.

Additionally, as the shading increases with the increasing planting density or with the intercropping with forest species, the incidence of Sigatoka might decrease and so the use of fungicides (Cavalcante et al. 2014). These authors verified that D'Angola cultivars (genomic group AAB, Musa spp.), grown in a spacing of $3.0 \mathrm{~m} \times 3.0 \mathrm{~m}$, shaded by rubber trees, were less harmed by Black Sigatoka due to the absence or reduction of dew and light, as the severity of the disease is related to insolation, air temperature and relative humidity.

Studies on lowering the amount of irrigation water, associated with high planting densities of bananas grown under semiarid conditions, are still 
scarce in the literature. It is expected that the increase in planting density and decrease in irrigation depth may influence the precocity and yield of crops. The use of different irrigation depths and planting densities is assumed to cause changes in the soil moisture, what, with the climate, may affect the water status of plants. This directly influences the plant growth, development and crop yield. It is expected that certain combinations of planting density higher than what is commonly used and irrigation depth below $100 \%$ of the ETc can lead to a lower use of irrigation water, maintenance of yield or its boost, and increase in the water-use efficiency, which significantly contributes to the sustainability of water and other natural resources. These are relevant topics currently under discussion and that will contribute to the sustainability and resilience of fruit production.

This study aimed to evaluate the influence of combinations of irrigation depths and planting densities on precocity, yield and water-use efficiency of BRS Platina banana plants, in the semiarid region of the Bahia state, Brazil.

\section{MATERIAL AND METHODS}

The study was carried out in a banana orchard planted in July 2016, in a Red-Yellow Latosol (Oxysol) with a medium texture. At the depths of $0-0.20 \mathrm{~m}$ and $0.20-0.40 \mathrm{~m}$, the physical characteristics are, respectively: density of $1.58 \mathrm{~kg} \mathrm{dm}^{-3}$ and $1.63 \mathrm{~kg} \mathrm{dm}{ }^{-3} ; 0.667 \mathrm{~kg} \mathrm{~kg}^{-1}$ and $0.613 \mathrm{~kg} \mathrm{~kg}^{-1}$ of sand; $0.150 \mathrm{~kg} \mathrm{~kg}^{-1}$ and $0.157 \mathrm{~kg} \mathrm{~kg}^{-1}$ of silt;
$0.183 \mathrm{~kg} \mathrm{~kg}^{-1}$ and $0.230 \mathrm{~kg} \mathrm{~kg}^{-1}$ of clay. The water contents at $-10 \mathrm{kPa}$ and $-1,500 \mathrm{kPa}$ were $0.20 \mathrm{~m}^{3} \mathrm{~m}^{-3}$ and $0.11 \mathrm{~m}^{3} \mathrm{~m}^{-3}$, respectively. The experimental area of the Instituto Federal Baiano, campus Guanambi, is located in the irrigation district of Ceraíma (14'13'30"S, 42\%46'53"W and $545 \mathrm{~m}$ of altitude), Bahia state, Brazil. The average annual rainfall in the area, based on a historic series of thirty years, is $680 \mathrm{~mm}$ and the mean temperature is $25.78^{\circ} \mathrm{C}$. The maximum and minimum temperatures and reference evapotranspiration were recorded at about $100 \mathrm{~m}$ away from the experimental area (Figure 1A).

The experiment aimed at evaluating irrigation depths and planting densities used for BRS Platina bananas (AAAB) and their influence on yield, production characteristics (hand weight and number of hands per bunch), precocity (number of days to harvest) and water-use efficiency, in the first production cycle.

AABB refers to the BRS Platina genome group. The letters A and B are derived from Musa acuminate and Musa balbisiana, respectively. It is a cross between AAB (Musa acuminate x Musa balbisiana) and AA (Musa acuminata). BRS Platina is a tetraploid (AABB) hybrid, previously known as PA42-44 [PA stands for Prata-Anã, which is the mother; 42 is the father's number, which is a male M. acuminate (AA) called M53; and 44 is the number designated to the selected cross]. This hybrid was developed by a Brazilian banana breeding program coordinated by the Embrapa Mandioca e Fruticultura and was derived from a cross between the triploid
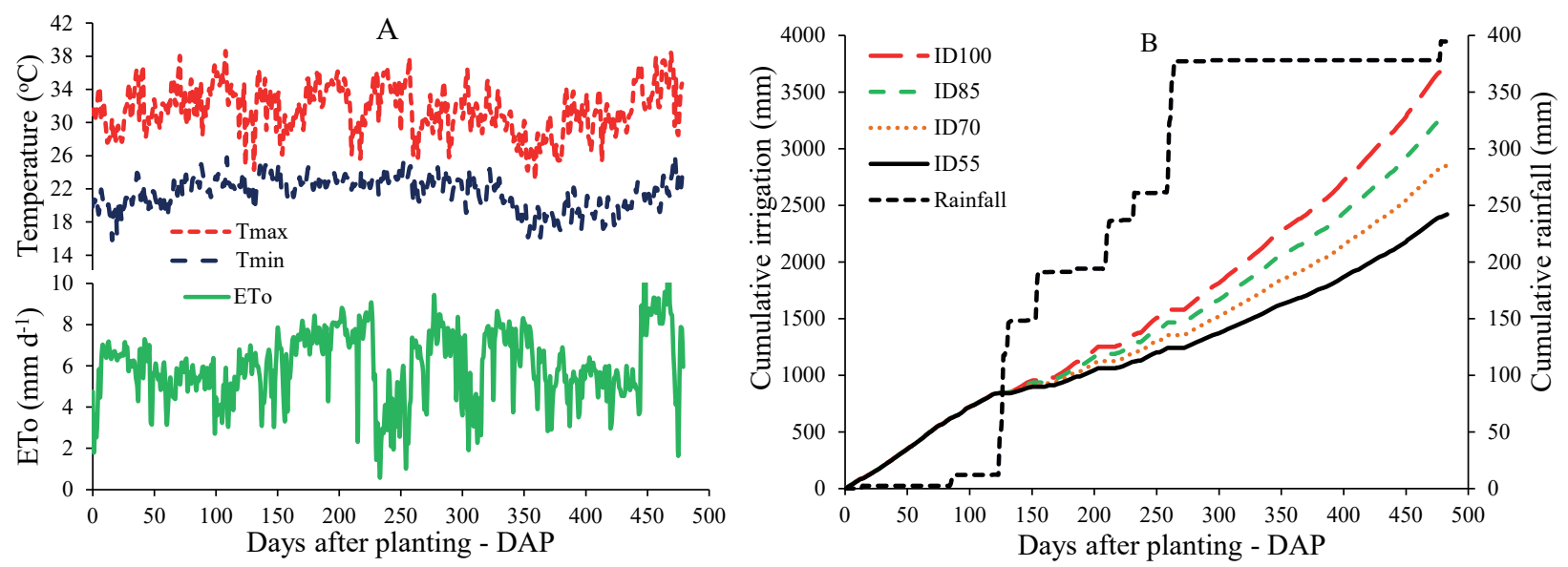

Figure 1. Maximum (Tmax) and minimum (Tmin) temperatures and reference evapotranspiration - ETo (A), cumulative irrigation at depths of $100 \%$ (ID100), $85 \%$ (ID85), $70 \%$ (ID70) and $55 \%$ (ID55) of the ETc and rainfall during the experimental period (B). 
(AAB) variety Prata-Anã and the diploid (AA) acuminate M53. Micro-propagated plantlets were used at transplanting and the crop practices followed the recommendations for the crop (Rodrigues et al. 2015).

Soil samples were collected for chemical characterisation before transplanting (Table 1). The area was sub-soiled, ploughed, harrowed and furrowed at a spacing of $2.5 \mathrm{~m}$ between row plantings. Planting holes were drilled with a mechanical auger coupled to the power take-off of a tractor, respecting the spacing between the plants assigned to each treatment.

The micronutrients B $(0.5 \%), \mathrm{Cu}(0.3 \%), \mathrm{Mn}$ $(0.3 \%)$ and $\mathrm{Zn}(1 \%)$ were monthly applied to plants by foliar feeding, until flowering. After flowering, micronutrient fertilizations were via rhizome, applied once to the plantlet removed (Rodrigues et al. 2007).

A randomized block design, arranged in splitplots, with four replicates, was used. The irrigation depths $(55 \%, 70 \%, 85 \%$ and $100 \%$ of the crop evapotranspiration - ETc) were assigned to the plot and the planting densities of 1,600 plants ha ${ }^{-1}$

Table 1. Chemical attributes of the soil from the experimental area before planting.

\begin{tabular}{|c|c|c|}
\hline \multirow{2}{*}{ Attributes } & \multicolumn{2}{|c|}{ Depth (m) } \\
\hline & $0.00-0.20$ & $0.20-0.40$ \\
\hline $\mathrm{pH}^{(1)}$ & 7.63 & 7.55 \\
\hline $\mathrm{OM}^{(2)}\left(\right.$ dag $\left.\mathrm{kg}^{-1}\right)$ & 2.08 & 0.45 \\
\hline $\mathrm{P}^{(3)}\left(\mathrm{mg} \mathrm{dm}^{-3}\right)$ & 563.90 & 127.40 \\
\hline $\mathrm{K}^{(3)}\left(\mathrm{mg} \mathrm{dm}{ }^{-3}\right)$ & 483.50 & 273.00 \\
\hline $\mathrm{Na}^{(3)}\left(\mathrm{cmol}_{\mathrm{c}} \mathrm{dm}^{-3}\right)$ & 0.10 & 0.10 \\
\hline $\mathrm{Ca}^{(4)}\left(\mathrm{cmol}_{\mathrm{c}} \mathrm{dm}^{-3}\right)$ & 4.78 & 2.45 \\
\hline $\mathrm{Mg}^{(4)}\left(\mathrm{cmol}_{\mathrm{c}} \mathrm{dm}^{-3}\right)$ & 2.25 & 1.48 \\
\hline $\mathrm{Al}^{(4)}\left(\mathrm{cmol}_{\mathrm{c}} \mathrm{dm}^{-3}\right)$ & 0.00 & 0.00 \\
\hline $\mathrm{H}+\mathrm{Al}^{(5)}\left(\mathrm{cmol}_{\mathrm{c}} \mathrm{dm}^{-3}\right)$ & 0.80 & 0.80 \\
\hline $\mathrm{SB}\left(\mathrm{cmol}_{\mathrm{c}} \mathrm{dm}^{-3}\right)$ & 8.33 & 4.68 \\
\hline $\operatorname{CEC}\left(\mathrm{cmol}_{\mathrm{c}} \mathrm{dm}^{-3}\right)$ & 8.33 & 4.68 \\
\hline $\operatorname{ECEC~}\left(\mathrm{cmol}_{\mathrm{c}} \mathrm{dm}^{-3}\right)$ & 9.18 & 5.50 \\
\hline$V(\%)$ & 91.25 & 85.00 \\
\hline $\mathrm{B}^{(6)}\left(\mathrm{mg} \mathrm{dm}^{-3}\right)$ & 0.78 & 0.65 \\
\hline $\mathrm{Cu}^{(3)}\left(\mathrm{mg} \mathrm{dm}^{-3}\right)$ & 1.38 & 0.43 \\
\hline $\mathrm{Fe}^{(3)}\left(\mathrm{mg} \mathrm{dm}{ }^{-3}\right)$ & 19.53 & 22.35 \\
\hline $\mathrm{Mn}^{(3)}\left(\mathrm{mg} \mathrm{dm}^{-3}\right)$ & 89.48 & 50.33 \\
\hline $\mathrm{Zn}^{(3)}\left(\mathrm{mg} \mathrm{dm}^{-3}\right)$ & 32.73 & 3.00 \\
\hline P-rem ${ }^{(7)}\left(\mathrm{mg} \mathrm{L}^{-1}\right)$ & 40.00 & 38.55 \\
\hline $\mathrm{EC}\left(\mathrm{dS} \mathrm{m} \mathrm{m}^{-1}\right)$ & 0.68 & 0.35 \\
\hline $\begin{array}{l}{ }^{(1)} \mathrm{pH} \text { in water; }{ }^{(2)} \text { colorimetry; } \\
{ }^{(5)} \mathrm{pH} \text { SMP; }{ }^{\left({ }^{6}\right)} \text { extractor: CaC } \\
\text { ECEC: effective caution exc } \\
\text { at } \mathrm{pH} 7 \text {; V: base saturation } \\
\mathrm{dag} \mathrm{kg}^{-1}=\% ; \mathrm{mg} \mathrm{dm}^{-3}=\mathrm{ppn}\end{array}$ & $\begin{array}{l}\text { ch-1 extraction } \\
\text { uilibrium solut } \\
\text { capacity; CEC: } \\
\text { : remaining P; } \\
\mathrm{dm}^{-3}=0.01 \mathrm{~m}\end{array}$ & $\begin{array}{l}\text { xtractor } 1 \mathrm{mo} \\
\text { SB: sum of b } \\
\text { exchange cap } \\
\text { ctric conduct }\end{array}$ \\
\hline
\end{tabular}

( $2.5 \mathrm{~m} \times 2.5 \mathrm{~m}), 2,000$ plants ha-1 $(2.5 \mathrm{~m} \times 2.0 \mathrm{~m})$, 2,666 plants ha ${ }^{-1}(2.5 \mathrm{~m} \times 1.5 \mathrm{~m})$ and 3,333 plants ha $^{-1}$ $(2.5 \mathrm{~m} \times 1.2 \mathrm{~m})$ were assigned to the split-plot. Plantlets were transplanted on 12 July 2016 and the plots were fully and equally irrigated up to 120 days after the transplanting (DAT) and, from then, at 448 DAT, the irrigation depths assigned to each plot were applied.

The amount of water applied was based on the crop evapotranspiration (ETc), which is a product of the reference evapotranspiration (ETo) by the modified Penman-Monteith method and crop coefficient $(\mathrm{Kc})$. The $\mathrm{Kc}(0.58$ at the onset of the experiment) gradually increased up to 1.4 at 294 DAT and, from then, it remained constant until the harvest of the first cycle, as indicated by Borges et al. (2011) for Prata-Anã in the region of Janaúba, north of the Minas Gerais state, Brazil: Kc $=0.704-6.443 \mathrm{x}$ $10^{-3} \mathrm{DAT}+6.437 \times 10^{-5} \mathrm{DAT}^{2}-1.174 \times 10^{-7} \mathrm{DAT}^{3}$; $\mathrm{R}^{2}=0.978$. This equation was used because the climate of the region where this study was carried out is similar to the climate of the northern Minas Gerais state. If it rained, the amount of rain water was deducted from the ETc, to correct the irrigation running time. The amount of water applied to each plot, as well as the total amount of rain that occurred during the conduction of the experiment, are shown in Figure 1B.

A micro-sprinkler irrigation system, with emitters of $127 \mathrm{~L} \mathrm{~h}^{-1}$ flow rate and application efficiency of $84 \%$ (Brito et al. 2016), was used. The spacing was $4.0 \mathrm{~m}$ between emitters and $5.0 \mathrm{~m}$ between laterals.

The harvest of bunches began at 412 DAT and ended at 486 DAT. Generally, in Prata-type banana plants, the period from planting to harvest ranges from 360 to 400 days. However, since plantlets used at transplanting were uneven and several of them died, replanting was necessary, what contributed to delaying the harvest. At harvest, the number of fruits and fruit weight per hand were recorded, what allowed determining the precocity and yield of hands. Conversely, the water-use efficiency was obtained by the ratio between the hands yield and gross irrigation depth applied.

The number of fruits, hands weight, number of days to harvest, yield and water-use efficiency were subjected to analysis of variance. As significant interactions were not found, the effects of the main factors were assessed using regression analysis for the 
irrigation depths and planting densities. The choice of the models took into account the significance of beta coefficients by the t-test and the magnitude of the coefficient of determination by $5 \%$.

\section{RESULTS AND DISCUSSION}

As for simple effects, the factor planting density was significant for all the varieties under study, though, concerning only the irrigation depth, this factor was not significant for yield, hands weight and days to harvest (Table 2). There were no significant interactions between irrigation depths and planting densities for the variables analyzed.

The decrease in the irrigation depth did not reduce yield (Figure $3 \mathrm{~A}$ ), despite reducing the number of fruits (Figure 2A), unlike some results found in the literature (Azevedo \& Bezerra 2008), that show different findings, in which yield rises with increasing irrigation depths. However, as noted herein, in higher plant densities, the lowest irrigation depths resulted in an increased yield. As the effect was independent,

Table 2. Analysis of variance for yield, water-use efficiency (WUE), days to harvest, hand weight and number of fruits under different planting densities (PD) and irrigation depths (ID).

\begin{tabular}{|c|c|c|c|c|c|c|c|c|c|c|c|c|c|c|c|c|}
\hline \multirow{2}{*}{ SV } & \multirow{2}{*}{ DF } & \multicolumn{3}{|c|}{ Yield } & \multicolumn{3}{|c|}{ WUE } & \multicolumn{3}{|c|}{ Days to harvest } & \multicolumn{3}{|c|}{ Hands weight } & \multicolumn{3}{|c|}{ Number of fruits } \\
\hline & & MS & Fc & $\operatorname{Pr}>\mathrm{Fc}$ & MS & $\mathrm{Fc}$ & $\operatorname{Pr}>\mathrm{Fc}$ & MS & $\mathrm{Fc}$ & $\operatorname{Pr}>\mathrm{Fc}$ & MS & $\mathrm{Fc}$ & $\operatorname{Pr}>\mathrm{Fc}$ & MS & $\mathrm{Fc}$ & $\mathrm{Pr}>\mathrm{Fc}$ \\
\hline Block & 3 & 211.05 & 7.67 & 0.0075 & 29.51 & 7.44 & 0.0083 & $1,678.02$ & 8.37 & 0.0057 & 18.02 & 14.42 & 0.0009 & 241.17 & 4.87 & 0.0279 \\
\hline ID & 3 & 32.61 & 1.19 & 0.3688 & 25.87 & 6.52 & 0.0123 & 234.04 & 1.17 & 0.3749 & 3.45 & 2.76 & 0.1037 & 246.43 & 4.98 & 0.0263 \\
\hline Error 1 & 9 & 27.51 & & & 3.97 & & & 200.50 & & & 1.25 & & & 49.48 & & \\
\hline PD & 3 & 327.26 & 13.76 & 0.0000 & 47.32 & 14.53 & 0.0000 & 563.86 & 3.07 & 0.0400 & 6.18 & 5.25 & 0.0041 & 173.13 & 3.91 & 0.0162 \\
\hline $\mathrm{ID} * \mathrm{PD}$ & 9 & 18.30 & 0.77 & 0.6451 & 2.56 & 0.79 & 0.6298 & 306.16 & 1.67 & 0.1335 & 0.46 & 0.39 & 0.9323 & 36.54 & 0.83 & 0.5972 \\
\hline Error 2 & 36 & 23.79 & & & 3.26 & & & 183.64 & & & 1.18 & & & 44.28 & & \\
\hline CV1 & & & 25.90 & & & 26.14 & & & 3.16 & & & 10.91 & & & 7.50 & \\
\hline CV2 & & & 24.09 & & & 23.68 & & & 3.02 & & & 10.59 & & & 7.10 & \\
\hline
\end{tabular}

SV: Source of variation; DF = degree of freedom.
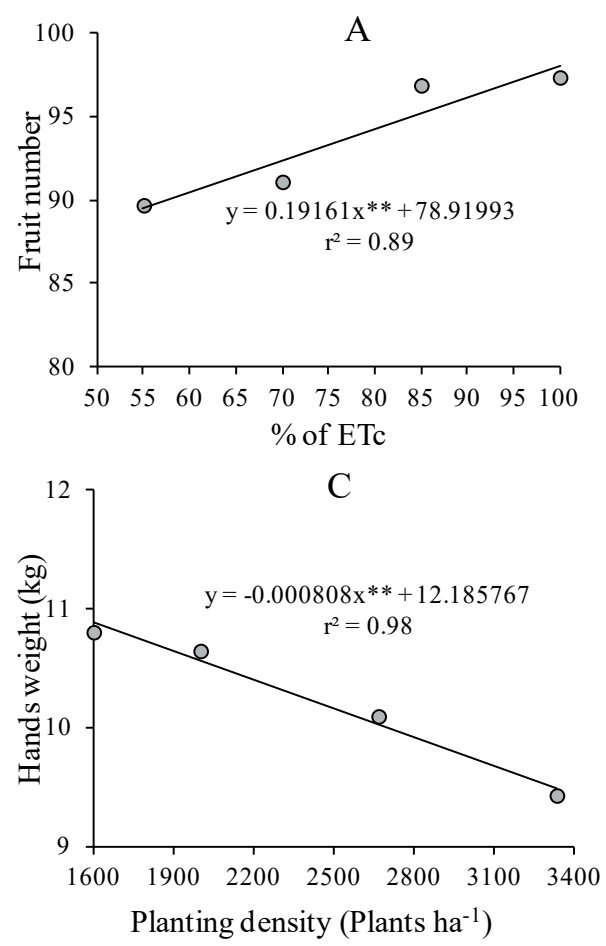
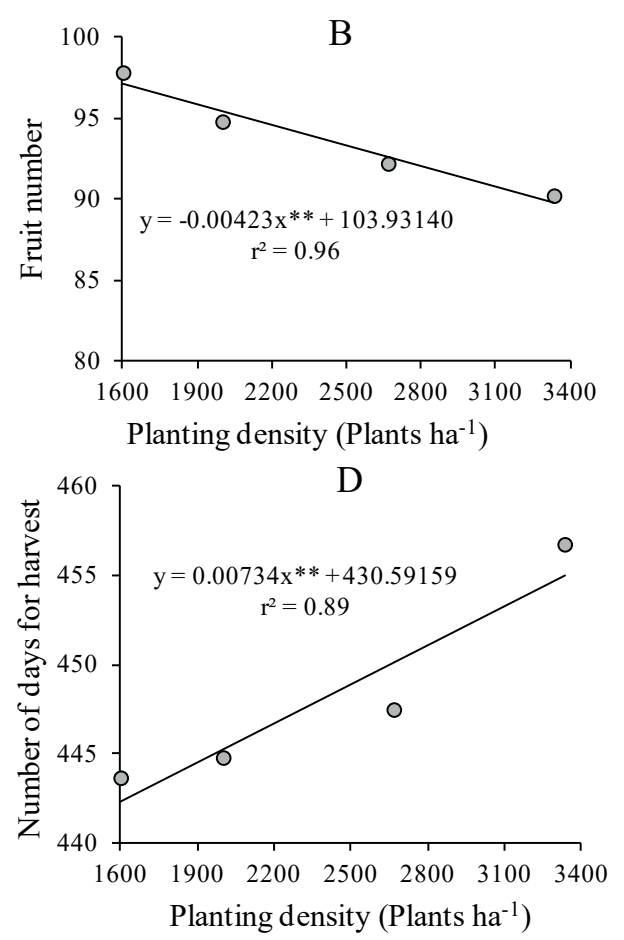

Figure 2. Number of fruits as a function of the ETc (A); and number of fruits (B), hands weight (C) and number of days to harvest (D) as a function of planting density for BRS Platina. * Significant at 0.05 by the $\mathrm{t}$-test; $* *$ significant at 0.01 by the $\mathrm{t}$-test. 
by putting together the highest yield means and the lowest yields at the lowest depths and planting densities, the yield amplitude was low, what, with the variation, contributed to the lack of difference.

A reduction of $45 \%$ in the ETc, despite the rain events during flowering, between 250 and 280 DAT (Figure 1B), was not enough to cause a water deficit in the soil, so it did not negatively affect flowering, hence the production was not affected either. The regression model adjusted to the data estimates a decrease of 0.00426996 fruits to each additional plant in the stand. The increase in planting density from 1,600 plants ha ${ }^{-1}$ to 3,333 plants $\mathrm{ha}^{-1}$ resulted in a reduction of $7.77 \%$ in the number of fruits, varying from 97.83 to 90.23 . These results agree with Pereira et al. (2000), who observed no influence of spacing on the number of Prata-Anã fruits. Nonetheless, these authors worked with lower planting densities (between 879 plants ha ${ }^{-1}$ and 1,666 plants ha ${ }^{-1}$ ).

The increase in the planting density decreased the number of fruits (Figure 2B) and hands weight (Figure 2C). However, in terms of yield, a linear increase of $67.14 \%$ was verified (Figure 3B), from $15.5 \mathrm{t} \mathrm{ha}^{-1}$ with 1,600 plants ha-1 to $25.8 \mathrm{t} \mathrm{ha}^{-1}$ with
3,333 plants $\mathrm{ha}^{-1}$. In spite of these changes, all fruits were longer than $14 \mathrm{~cm}$ and had a diameter above $31.75 \mathrm{~mm}$, what qualifies the fruits as first class bananas, according to the regional marketing classification. A higher planting density interferes with the competition for water, nutrients and luminosity, what reduces the number of fruits and hands weight, though the proportional reduction in the number of fruits and hands weight is much lower than the proportional increase in planting density, hence the increase in yield. Belalcázar-Carvajal (1991) pointed out that the increase in yield per unit area with the increasing planting density is expected. Nevertheless, a reduction in the bunch weight, number of fruits and hands, fruit diameter, fruit length and fruit weight might take place, what may affect the commercial classification of the fruit.

Regarding the hands yield (Figure 3B), the model estimates an increment of about $0.0059 \mathrm{t} \mathrm{ha}^{-1}$ of hands to each additional plant in the stand. The results show an increase in the net yield per unit area as planting density increases, in the first production cycle. The maximum hands yield $\left(25.84 \mathrm{t} \mathrm{ha}^{-1}\right)$ recorded in the first cycle herein for BRS Platina
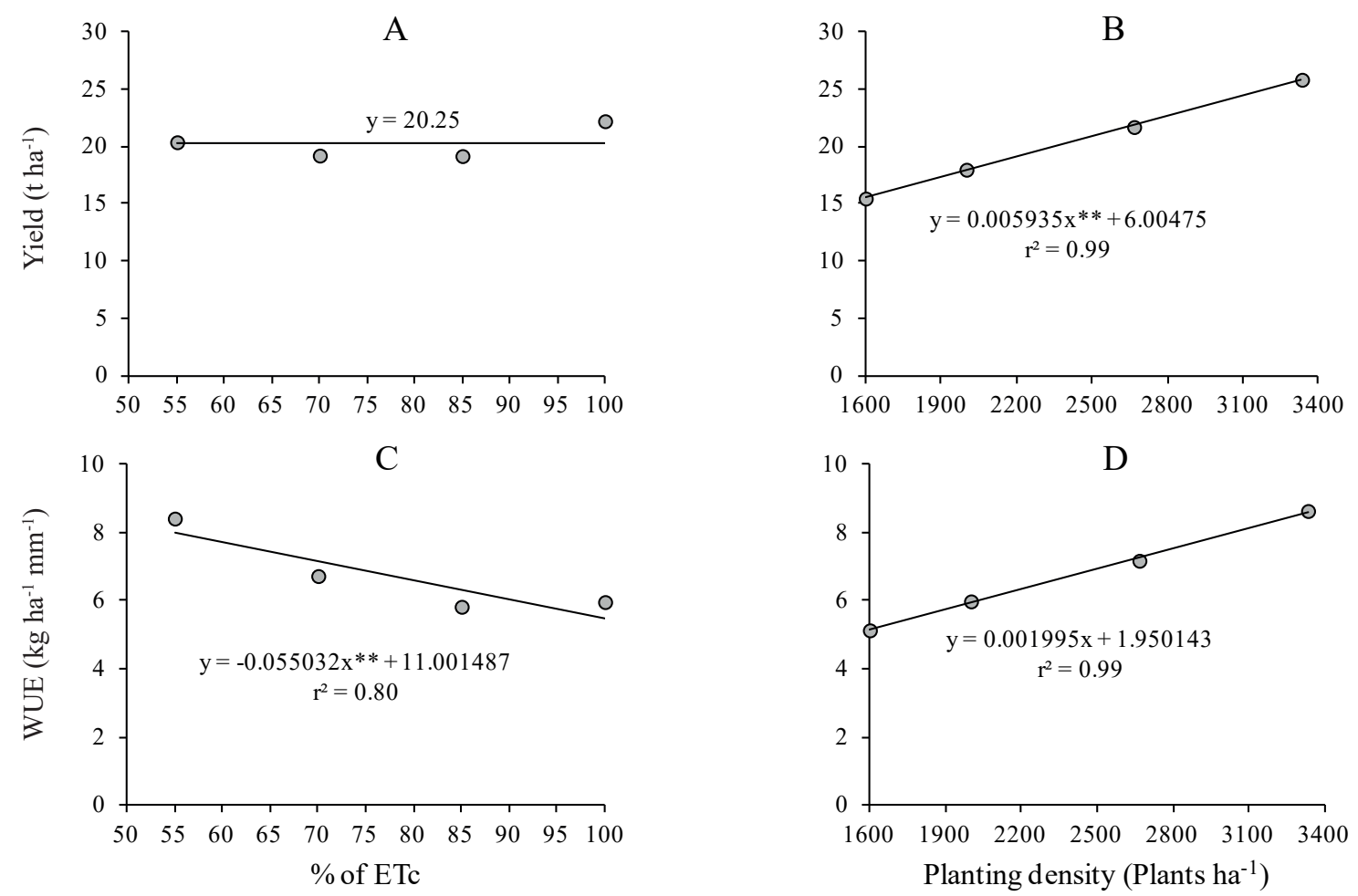

Figure 3. Yield of BRS Platina banana plants under irrigation depths (A), planting densities (B), water-use efficiency (WUE) under irrigation depths $(C)$ and planting densities (D) in the first production cycle. * Significant at a 0.05 significance level by the $\mathrm{t}$-test; ${ }^{* *}$ significant at a 0.01 significance level by the $\mathrm{t}$-test. 
represents the actual yield, which was obtained by correcting the plants effectively harvested, in relation to the initial planting density. These values, normally observed for Prata-type banana plants in the first cycle, are similar to those of Marques et al. (2018), in which $21.31 \mathrm{t} \mathrm{ha}^{-1}$ of hands were recorded from a population of 2,000 plants ha-1. Conversely, Donato et al. (2015b) reported that well-managed banana plantations under better conditions of climate, such as maximum temperatures below $34{ }^{\circ} \mathrm{C}$, less windrelated damage and higher relative humidity, i.e., favoring a higher carboxylation and instantaneous water-use efficiency (Donato et al. 2015a, Arantes et al. 2016 and 2018, Ramos et al. 2018), may yield more than $40 \mathrm{t} \mathrm{ha}^{-1}$ cycle $^{-1}$ (high yield $>32 \mathrm{t} \mathrm{ha}^{-1}$ cycle $\left.^{-1}\right)$, particularly from the second production cycle on.

The lack of irrigation depth effect on the yield of the first production cycle was also observed by Santos et al. (2016), who, by studying Prata-Anã and BRS Platina, did not verify differences in yield between the two cultivars or lack of effects for lowering the irrigation depth, although the yield recorded herein $\left(20.25 \mathrm{t} \mathrm{ha}^{-1}\right)$ was higher than that found by Santos et al. (2016) $\left(9.59 \mathrm{tha}^{-1}\right)$. It is worth noting that, in the experiment carried out by Santos et al. (2016), the planting density was 1,333 plants ha $^{-1}$ and the plants were watered by drip irrigation. In Pentecoste, Ceará state, Brazil, Azevedo \& Bezerra (2008) verified that yields of Prata-Anã and Pacovan linearly increased as the irrigation depth increased. The irrigation depths varied from $1,883.7 \mathrm{~mm}$ to $3,747.1 \mathrm{~mm}$ and the average yields were $15.15 \mathrm{t} \mathrm{ha}^{-1}$ and $17.80 \mathrm{t} \mathrm{ha}^{-1}$, respectively for Prata-Anã and Pacovan.

Furthermore, increasing the planting density of BRS Platina from 1,600 plants ha-1 to 3,333 plants hadelays theharvest by approximately 13 days(Figure 3D), but the same behaviour was not observed when reducing the irrigation depth. The model estimates an increase of approximately 7 days to each additional 1,000 plants in the stand over the period from planting to harvest (Figure 3 ). Increasing the planting density from 1,600 plants ha $\mathrm{a}^{-1}$ to 3,333 plants $\mathrm{ha}^{-1}$ resulted in an increase of $2.95 \%$ in the number of days from planting to harvest, with a variation from 443.69 to 456.77 days. These results differ from Pereira et al. (2000), who did not observe any influence of spacing on the harvesting time of Prata-Anã, which averages 411 days in the northern region of the Minas Gerais state, Brazil. These authors reported that the cycle length is highly influenced by the increase in the planting density, tending to be higher in the following cycles as the late-developing plants are self-shaded.

The water-use efficiency linearly decreased with the irrigation depth increasing from $55 \%$ to $100 \%$ of the ETc or $3253.8 \mathrm{~mm}$ applied (Figure $3 \mathrm{C}$ ), and linearly increased with the planting density increasing from 1,600 plants ha ${ }^{-1}$ to 3,333 plants ha-1 (Figure 3D). The reduction in the irrigation depth with a constant yield, as previously explained, and the higher planting density increased the yield and so the water-use efficiency. This demonstrates that the higher planting density may improve the water-use efficiency, even using a lower irrigation depth. This might be linked to the increased planting density, as this increase is a way of improving the thermal comfort within the banana plantation (Donato et al. 2015a) and protecting plants from strong winds. This protecting effect is due to the higher number of banana plants used and is particularly useful in regions or seasons with high temperatures, solar radiation and strong winds.

The leaf temperature ( $\mathrm{Lt}$ ) varies directly with air temperature, as illustrated by Donato et al. (2017), who found a correlation with high magnitude and significance for Prata-Anã bananas grown in Nova Porteirinha, Minas Gerais state, Brazil, in September, with $\mathrm{Lt}=-13.347+1.66935 \mathrm{Tmax}$, and $\mathrm{r}=0.96$. Similarly, $\mathrm{Lt}=9.80719+1.011498$ Tmax, and $\mathrm{r}=$ 0.91 , was found under the same conditions of this study (place and year). The higher leaf temperature increased the transpiration and reduced the instant water-use efficiency (Santos et al. 2017). On the other hand, temperatures close to the optimal one for photosynthesis in banana plants $\left(27^{\circ} \mathrm{C}\right.$ ) (Donato et al. $2015 \mathrm{c}$ ) contribute to the increase in the carboxylation efficiency of rubisco (Arantes et al. 2016, Ramos et al. 2018) and water-use efficiency (Arantes et al. 2018), leading to higher net photosynthesis and yields, what ensures the application of lower irrigation depths. In this study, temperatures close to optimal occurred in midyear months, while temperatures hindering photosynthesis (higher than $34{ }^{\circ} \mathrm{C}$ ) were recorded mainly in September, October, February and March.

Similar findings on reducing irrigation depths were obtained by Santos et al. (2016), who observed, in Prata-Anã and BRS Platina, a decrease in the water-use efficiency with increasing irrigation depths, since yield is not consistent with increasing 
irrigation depths, so there were no statistically significant differences for yield. The same authors found a water-use efficiency of $7.05 \mathrm{~kg} \mathrm{ha}^{-1} \mathrm{~mm}^{-1}$ for an irrigation depth with $100 \%$ of the ETc. However, these authors verified that the water-use efficiency increases in the remaining cycles, possibly due to the increase in yield or, in some cases, reduction of the total amount of water applied because of the shortening of the cycle. Azevedo \& Bezerra (2008) found a water-use efficiency of $5.17 \mathrm{~kg} \mathrm{ha}^{-1}$ and $7.77 \mathrm{~kg} \mathrm{ha}^{-1}$ for the irrigation depths of $3,747.1 \mathrm{~mm}$ and 1,883.7 mm, respectively, for Prata-Anã and Pacovan, i.e., a reduction in water-use efficiency by $50 \%$. A twofold increase in irrigation depth led to an increase of only $30 \%$ in yield, from $14.63 \mathrm{t} \mathrm{ha}^{-1}$ to $19.30 \mathrm{t} \mathrm{ha}^{-1}$, as the irrigation depth increased, hence the reduction in water-use efficiency. Thus, even by finding a yield increase that is significant $(\mathrm{p}<0.01)$, it might be feasible using lower irrigation depths in regions where water is lacking.

In the present study, the model estimates a water-use efficiency of $5.50 \mathrm{~kg} \mathrm{ha}^{-1} \mathrm{~mm}^{-1}$ for $100 \%$ of the ETc and may increase to $8.6 \mathrm{~kg} \mathrm{ha}^{-1} \mathrm{~mm}^{-1}$, provided that planting density is 3.333 plants ha $^{-1}$, since the same irrigation depth would be used for more plants per unit area and higher yields. Herein, in spite of the good yields of the first cycle, the water-use efficiency was low, due to the application of a larger amount of water, as the first cycle becomes longer.

When increasing the number of plants, particularly in regions or seasons with high temperatures, high solar radiation, low relative humidity, i.e., high vapor pressure deficit conditions (dry atmosphere), the thermal conditions within the banana plantation improves, thereby increasing the carboxylation efficiency and water-use efficiency, so that the same yield can be attained using less water. Another factor to be taken into account is that BRS Platina is a tetraploid hybrid and may be recommended for water-deficit conditions owing to its low response to increasing irrigation depths, if compared to cultivars belonging to the Cavendish subgroup, e.g., Grand Nain (AAA). Cultivars with a B genome exhibit higher aquaporin synthesis (Henry et al. 2011), what forms canals that are selective to flowing water through the membrane, accumulation of proline and synthesis of abscisic acid (Vanhove et al. 2012).

Aquaporins (water channel proteins) are involved with the membrane transport of gases, solutes and ions, and their genes are found in every plant organ and tissue. These proteins are essential for water and nutrient uptake by roots, photosynthesis, transpiration and adaptation to environment-related stresses (Gaspar, 2011). Xu et al. (2014) identified a plasma membrane aquaporin gene in the banana plant that induces drought tolerance by reducing the membrane damage, improving the ionic distribution by maintaining the osmotic adjustment with a high cytosolic $\mathrm{K}^{+} / \mathrm{Na}^{+}$ratio, and downregulating genes responsive to $\mathrm{ABA}$, thereby increasing the plant survival rate.

\section{CONCLUSIONS}

1. Increasing the planting density up to 3,333 plants $\mathrm{ha}^{-1}$ decreases the hands weight and the number of fruits of BRS Platina banana plants, although it lengthens the harvest period and increases the yield and water-use efficiency in the first production cycle, regardless of the irrigation depth used;

2. Increasing the irrigation depth also increases the number of fruits, since it maintains yield and linearly reduces the water-use efficiency, regardless of the planting density;

3. A higher yield and water-use efficiency may be reached with a planting density up to 3,333 plants $\mathrm{ha}^{-1}$ and irrigation depth between $55 \%$ and $100 \%$ of the ETc.

\section{REFERENCES}

ARANTES, A. M. et al. Gas exchange in 'Pome' banana plants grown under different irrigation systems. Engenharia Agrícola, v. 38, n. 2, p. 197-207, 2018.

ARANTES, A. M. et al. Gas exchange in diferent varieties of banana Prata in semi-arid environment. Revista Brasileira de Fruticultura, v. 38, n. 2, p. 1-12, 2016.

AUJLA, M. S. et al. Cotton yield and water use efficiency at various levels of water and $\mathrm{N}$ through drip irrigation under two methods of planting. Agricultural Water Management, v. 71, n. 1, p. 167-179, 2005.

AZEVEDO, J. H. O.; BEZERRA, F. M. L. Respostas de dois cultivares de bananeira a diferentes lâminas de irrigação. Revista Ciência Agronômica, v. 39, n. 1, p. 28 33, 2008.

BELALCÁZAR-CARVAJAL, S. L. El cultivo del plátano em el trópico. Cali: Feriva, 1991.

BORGES, A. L. et al. Irrigação e fertirrigação na cultura da banana. In: SOUSA, V. F. et al. Irrigação e fertirrigação em fruteiras e hortaliças. Brasília, DF: Embrapa Informação Tecnológica, 2011. p. 369-397. 
BRITO, C. F. B. et al. Desempenho de sistemas de irrigação por gotejamento com aplicação da água salina. Revista Agrotecnologia, v. 7, n. 1, p. 10-17, 2016.

CARVALHO, C. et al. Anuário brasileiro da fruticultura. Santa Cruz do Sul: Gazeta Santa Cruz, 2017.

CAVALCANTE, M. J. B. et al. Manejo fitotécnico da bananeira, cultivar D' Angola (AAB), visando ao controle da sigatoka-negra. Revista Caatinga, v. 27, n. 2, p. 201208, 2014.

DONATO, S. L. R. et al. Aspectos de ecofisiologia e estratégias de manejo da bananeira. In: ZUCOLOTO, M.; BONOMO, R. (Orgs.). Fruticultura tropical: diversificação e consolidação. Alegre: Caufes, 2017. p. 57-73.

DONATO, S. L. R. et al. Considerações ecofisiológicas e estratégias de manejo da bananeira. Informe Agropecuário, v. 36, n. 288 , p. $13-26,2015$ c.

DONATO, S. L. R. et al. Considerações sobre índices técnicos, de produção e econômicos para a cultura da bananeira. Informe Agropecuário, v. 36, n. 288, p. 114125,2015 b.

DONATO, S. L. R. et al. Eficiência de uso da água em bananeira. Informe Agropecuário, v. 36, n. 288, p. 46-61, 2015 a.

FLORI, J. E.; RESENDE, G. M.; PAIVA, L. E. Produção de bananeira 'Grande Naine' superadensada e irrigada no Vale do São Francisco. Revista Ciência e Agrotecnologia, v. 28 , n. 5, p. 1060-1065, 2004.

GASPAR, M. Aquaporinas: de canais de água a transportadores multifuncionais em plantas. Revista Brasileira de Botânica, v. 34, n. 4, p. 481-491, 2011.

HENRY, I. M. et al. Structure and regulation of the Asr gene family in banana. Planta, v. 234, n. 4, p.785-798, 2011.

INSTITUTO BRASILEIRO DE GEOGRAFIA E ESTATÍSTICA (IBGE). Sistema IBGE de recuperação automática - SIDRA. 2018. Available at: <https://sidra. ibge.gov.br/home/pmc/brasil>. Access on: 09 Apr. 2018.

JENSEN, M. E. Sustainable and productive irrigated agriculture. In: HOFFMAN, G. J. et al. Design and operation of farm irrigation systems. 2. ed. Saint Joseph: ASABE, 2007. p. 33-56.

LANGDON, P. W. et al. The influence of planting density on the production of 'Goldfinger' (Musa spp., AAAB) in the subtropics. Scientia Horticulturae, v. 115, n. 3, p. 238-243, 2008.

MAHMOUD, H. H. Effect of different levels of planting distances irrigation and fertigation on yield characters of main crop cv. Grande Naine. Global Journal of Plant Ecophysiology, v. 3, n. 2, p. 115-121, 2013.
MARQUES, P. R. R. et al. Gas exchange and yield of Prata-type banana plants with fertilizer sources for organic management. African Journal of Agricultural Research, v. 13, n. 5, p. 272-280, 2018.

MELO, A. S. et al. Crescimento vegetativo, resistência estomática, eficiência fotossintética e rendimento do fruto da melancieira em diferentes níveis de água. Acta Scientiarum Agronomy, v. 32, n. 1, p. 73-79, 2010.

NOMURA, E. S. et al. Development and production of banana plant 'Grande Naine' under different planting densities in regions with natural occurrence of black leaf streak. Revista Brasileira de Fruticultura, v. 35, n. 2, p. 437-445, 2013.

OLIVEIRA, J. M.; COELHO FILHO, M. A.; COELHO, E. F. Crescimento da bananeira Grande Naine submetida a diferentes lâminas de irrigação em tabuleiro costeiro. Revista Brasileira de Engenharia Agrícola e Ambiental, v. 17, n. 10, p. 1038-1046, 2013.

PEREIRA JUNIOR, J. S. Nova delimitação do semiárido brasileiro. Brasília, DF: Centro de Documentação e Informação, 2007.

PEREIRA, M. C. T. et al. Crescimento e produção de primeiro ciclo da bananeira 'Prata Anã' (AAB) em sete espaçamentos. Pesquisa Agropecuária Brasileira, v. 35, n. 7, p. 1377-1387, 2000.

PRATA, C. R. et al. Densidade de plantio no crescimento e produção de plátano cv. D'Angola na Chapada do Apodi. Revista Agropecuária Técnica, v. 39, n. 1, p. 15-23, 2018.

RAMOS, A. G. O. et al. Evaluation of gas exchanges and production of genotypes of Maçã banana type cultivated in the semi-arid region of Bahia. Revista Brasileira de Fruticultura, v. 40, n. 3, e-500, 2018.

RODRIGUES, M. G. V. et al. Implantação e condução do bananal. Informe Agropecuário, v. 36, n. 288, p. 27-45, 2015.

RODRIGUES, M. G. V. et al. Nutrição e produção da bananeira 'PrataAnã' adubada com zinco e boro diretamente no rizoma, via muda desbastada. Revista Brasileira de Fruticultura, v. 29, n. 3, p. 645-651, 2007.

ROSAlES, F. E.; ALVAREZ, J. M.; VARGAS, A. Guia prática para la producción de plátano con altas densidades: experiencias de América Latina y el Caribe. Rome: Bioversity International, 2008.

SANTOS, M. R. et al. Gas exchange in 'BRS Princesa' banana (Musa spp.) under partial rootzone drying irrigation in the north of Minas Gerais, Brazil. Acta Agronomica, v. 66, n. 3, p. 378-384, 2017.

SANTOS, M. R. et al. Irrigation management strategy for Prata-type banana. Revista Brasileira de Engenharia Agrícola e Ambiental, v. 20, n. 9, p. 817-822, 2016. 
SIMSEK, M. et al. The effects of different irrigation regimes on cucumber (Cucumbis sativa L.) yield and yield characteristics under open field conditions. Agricultural Water Management, v. 73, n. 3, p. 173-191, 2005.

TEIXEIRA, L. A. J. et al. Ganhos de eficiência fertilizante em bananeira sob irrigação e fertirrigação. Revista Brasileira de Fruticultura, v. 33, n. 1, p. 272-278, 2011.

ULLOA CORTAZAR, A. M. et al. Effect of plant density on growth and yield in Barraganete plantain (Musa paradisiaca (L.) AAB cv. Curare enano) for a single harvest cutting in Provincia de Los Ríos, Ecuador. Acta Agronómica, v. 66, n. 3, p. 367-372, 2017.
VANHOVE, A. C. et al. Screening the banana biodiversity for drought tolerance: can an in vitro growth model and proteomics be used as a tool to discover tolerant varieties and understand homeostasis. Frontiers Plant Science, v. 3, n. 1, p. 1-10, 2012.

$\mathrm{XU}$, Y. et al. A banana aquaporin gene, MaPIP1;1, is involved in tolerance to drought and salt stresses. Plant Biology, v. 14, n. 59, p. 1-14, 2014.

ZHANG, Y. et al. Effect of soil water deficit on evapotranspiration, crop yield and water use efficiency in the north China plain. Agricultural Water Management, v. 64 , n. 1, p. 107-122, 2004. 